\title{
THE FUTURE OF DWELLING: ROCKING THE HOUSEBOAT
}

\author{
CAMILO CERRO \\ College of Architecture, Art and Design, American University of Sharjah, UAE
}

\begin{abstract}
According to the United Nations, presently, approximately 54\% of the world's population lives in urban areas, with the number expected to increase to $66 \%$ by 2050 . Urban areas that are ill prepared to deal with their present population needs will have to develop and manage housing, healthcare, education, transportation, infrastructure and food production for an additional 2.5 billion people. Because of this, managing urban areas has become one of the most important development challenges of our century. When we add to this equation climate change and shortage of land produced by the increase in the sea level, we end up with large populations with nowhere to place them. Communities near the water will have to start developing new typologies in housing designed to float as a means to adapt to the changes in the sea level produced by global warming. The following research is part of an on-going process of developing adaptable design of dwelling typologies for the immediate future. In this paper, I will be presenting a proposal for a floating dwelling typology designed to adapt to the evolution of three aspects of life: the social one, mainly dealing with how the idea of the traditional family has given way to multiple types of social micro-communities that are forcing residential design into a much more adaptable typological complexity; the labour aspect, estimating a growth on working online and of selfemployment, turning their residences into offices or micro-factories where they will produce, package and sell their products with the help of the internet using online marketplaces and the food production aspect, where the next generation dwelling unit will reclaim certain elements of farming and resettle them in the city.

Keywords: Systemic interdependence, floating dwelling, live/work/farm, third nature.
\end{abstract}

\section{INTRODUCTION}

As the sea level rises, humanity will need to become more comfortable with the idea of living on water. And even though living on water is nothing new from a vernacular perspective, in this paper, we will discuss the evolution of water dwelling ideas, into a modern floating housing typology. This typology explores design ideas around the systemic interdependence of three concepts: live, work and farm. Dwelling in general needs to address much more than just the requirements needed in a place for living, after the pandemic (COVID-19), the circumstances have proven that working from home is not only possible but a good alternative, which implies that a dwelling will have to also house space for small industry or professional services. In a similar way, the next generation of dwelling will reclaim certain elements of farming and resettle them in the city. Produce will be grown in-house through hydroponics or other high-tech irrigation systems designed to help the household cope with the cost of living. Residential design needs to get to a point where functional sustainability becomes a habitual part of the design process. Forcing smart technologies to be embedded in a systemic way in dwellings designed for adaptability and versatility. These new dwelling typologies will need to be designed for production and filtration of water, generation of energy, urban farming and the capacity to sustain a work environment. The idea is to move to a level of self-sufficiency that will be especially necessary in communities in areas where the rise in sea levels and the climate change crisis produce seasonal or permanent flooding. In these instances, the dwelling will need to float allowing for entire communities to adapt to the change preventing immigration, which would generate unwanted pressure in resources and infrastructure of 
adjacent areas. When neighbourhoods designed to float adapt to the environmental changes around them, living on water as independent floating communities existing in a sustainable symbiosis between the built and natural environments, we would not only have changed our conception of dwelling, but also the idea of city. This resultant system that we will call third nature will manifest as an urban proposal where sustainable design moves from the microto macro-scales: house to block to city, developing a systemic interdependency between the inhabitants and their surroundings as they participate in the development of a new type of environment for living. In this paper, we will explore through a journey from the vernacular to the modern, a series of philosophical and ethical ideas that will manifest on the design of a floating environment created to better the quality of life of its users and to lessen the burden that overpopulation is placing in cities, by creating a hybrid space for dwelling, farming and working.

\section{FIELD WORK: A BRIEF DIARY}

In the past years, I have been spending time in floating communities around the world documenting and understanding the social implications of living on or near water. In the summer of 2007, I went to the Lake Titicaca region in Peru to spend time visiting the Uru people near the town of Puno (Fig. 1). The Uru people predate the Incan civilization and were forced to move into the lake as a defensive tactic against the expansion of the Inca Empire. The Uru people live today as they did then on man-made islands made of living Totora reeds, which grow on the edges of the Lake Titicaca. The Totora (Schoenoplectus californicus) is a South American reed that can grow to a height of $6 \mathrm{~m}$ and is used by tying or weaving to make their islands, boats, furniture and dwellings. As the reeds disintegrate from the bottom of the island, which are about a meter thick, the Uru add more to the top of the island and this ongoing process keeps them afloat to perpetuity. The surface of the islands is soft, holding the weight of people, dwelling and land, which they bring from the edges of the lake and place over the reed for small-scale agriculture. Protein is added to their diet from fish from the lake and Guinea Pigs that they capture and leave to roam free on the islands until they get cooked. This people have incorporated into their dwellings a farming and a working component to better their quality of life. This community of over 4,000 inhabitants gets almost all their needs meet from the surrounding environment.

My experience with the Uru people left me interested in this field of research, but it was not until the summer of 2013 that I was able to do field work again. This time, I went to the villages of Kampong Khleang, Kampong Phluk and Pret Toal in Lake Tonle Sap, Cambodia (Fig. 2). With a maximum depth of $10 \mathrm{~m}$, this lake is the largest freshwater lake in Southeast Asia and changes its area from $3,000 \mathrm{~m}^{2}$ to $10,000 \mathrm{~m}^{2}$ between the dry and rainy seasons. The richness of this ecosystem has sustained the Khmer civilization for centuries and is still the
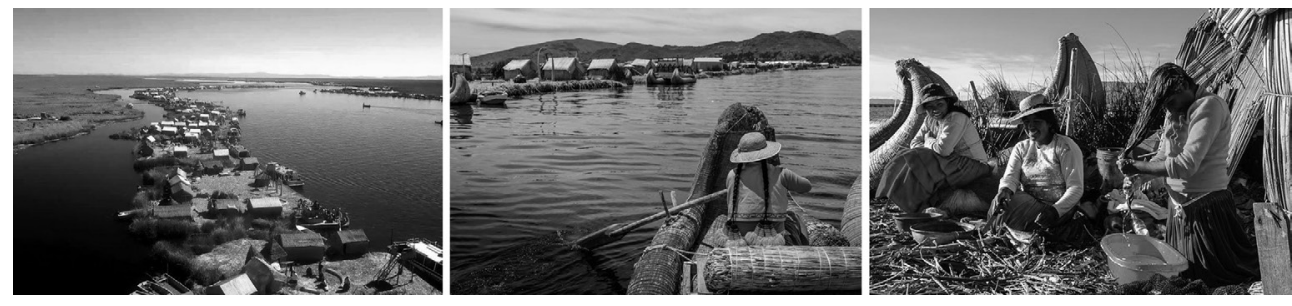

Figure 1: Floating village of Uru people in the Lake Titicaca near Puno in Peru. 

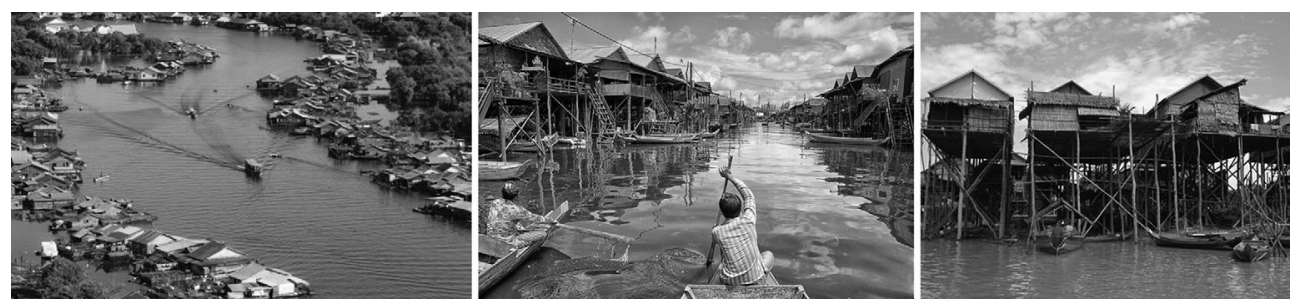

Figure 2: Villages of Kampong Khleang, Kampong Phluk and Pret Toal in Lake Tonle Sap, Cambodia.

food basket of this part of the world. With the monsoon, the rain brings change and adaptability, the population of the lake moves from being farmers to floating over their land and becoming fisherman as the rain floods their land. The villages have a combination of floating houses and houses on stilts. The floating ones use mainly metal and plastic barrels for floatation, leaving covered space for cooking, sleeping, storage and work (related to fishing), showing again that the dwelling needs to fulfil a variety of functions, some not normally associated with the western perception of residential living. In this sense, the dwellings in the lake serve two different functions, one when the water level is high and another when the water resides, and the land, full of nutrients, becomes the perfect farming soil until the next rainy season and the floods that come with it.

After my time in Cambodia, I took a boat up the Mekong River to the village of Luang Prabang in Laos. I stayed in Luang Prabang using it as a hub to explore the river on both directions. The idea was to see first-hand the interaction between different communities and the river. Communities next to rivers do not need to develop floating houses as long as the stilts they use to separate their dwellings from the water are strong and high enough to withstand the water level fluctuations that happen seasonally. Floating does take an important role on transportation being the main source of commerce in the area. Houses look to the river instead of away from it, making evident the importance of this resource to the communities that live by it. These communities build two level houses, with the first level used for storage and outdoor living during the dry season and allowing it to flood over the rainy season (Fig. 3). The capacity to still function as communities once the water takes over showed a level of adaptability that will be essential when dealing with climate change.

In the summer of 2014, I visited the villages of Yawnghwe and Kay Lar Ywa in Inle Lake in Myanmar (Fig. 4), where the whole community of the Intha people not only lives on the lake but also farms on floating fields over the water. The depth of the lake fluctuates from 2 $\mathrm{m}$ in the dry season to $3.5 \mathrm{~m}$ in the rainy season. The houses on stilts have two levels: the first level is used for storage and work, while the second serves as the dwelling. In these buildings, the second floor, just like in Laos, is designed to be flooded seasonally while the residential part of the house stays above water. The town has waterways with boat traffic in the same manner a town on land would around cars. The buildings are set in groupings surrounded by water ways designed for the turning radius of the long boats used by the locals. Speed bumps in the form of floating horizontal bamboo obstacles force the boats to slow down as they float above them, mirroring systems we normally see on land. Presently, Inle Lake is suffering from the environmental effects of increased population density and rapid growth in both agriculture and tourism. Sanitation in the villages around the lake is also an on-going concern for public health officials, due to untreated sewage (with $72 \%$ of households using 

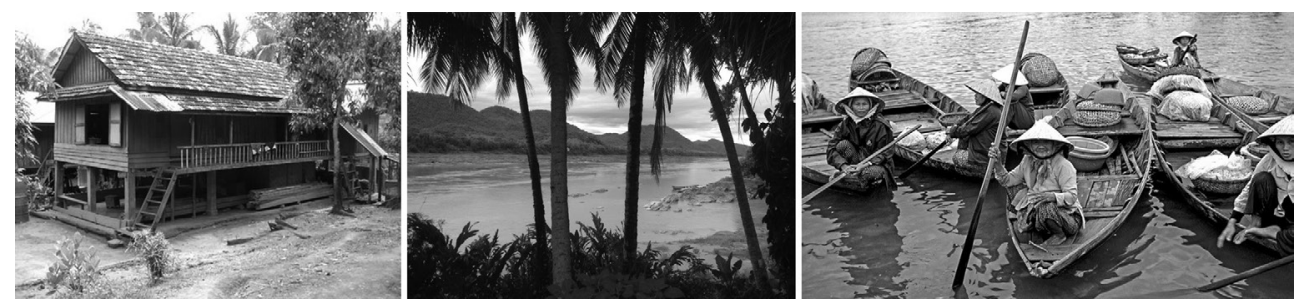

Figure 3: Villages on the Mekong River near Luang Prabang.
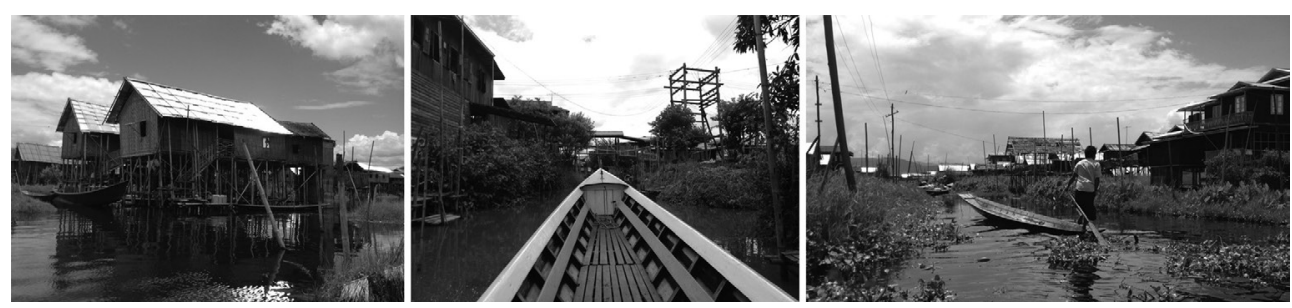

Figure 4: Villages of Yawnghwe and Kay Lar Ywa in Inle Lake in Myanmar.
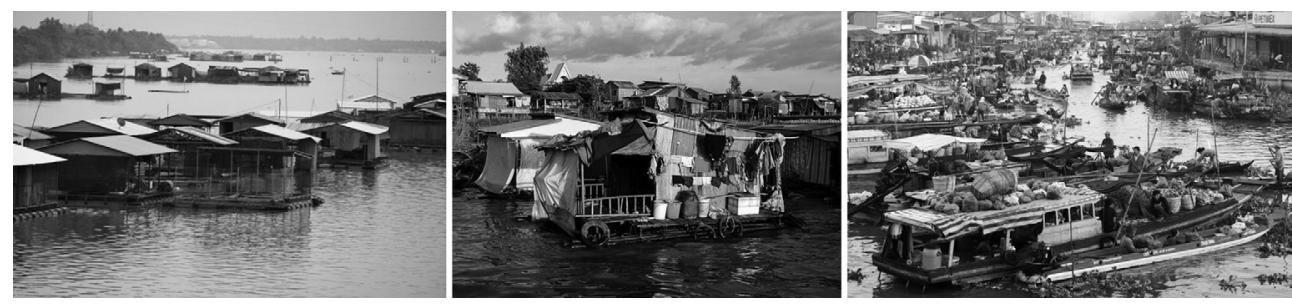

Figure 5: The Mekong Delta in Vietnam.

open pits, not latrines) and wastewater flowing into the lake. This community contrary to other previously mentioned has already lost its natural balance, but it is still a great example of a community using an urban approach to deal with transportation and adaptability to the rise of the water levels.

Next was Vietnam in 2015, where I spent some time in the Mekong delta (Fig. 5) south of Ho Chi Minh City. The fluctuations on the water level make the delta hard to access by car. In this area, people live on water, thanks to the stillness produced by the marsh. This is a very productive area of Vietnam, with rich soil and large numbers of fish farms, which has as a side effect some of the most amazing water markets I have visited. This area and Ha Long Bay in the north of the country are both great places where full working communities living on water can be observed. Part of what made these experiences consequential to my work is that in all cases I lived within the communities in floating houses or houses with stilts to be able to document structural systems and building techniques. The thing that was the most interesting to me was that for these dwelling systems to function, in all cases, the dwelling was built simply and out of local materials making maintenance easy and accessible. Materials are expensive, 

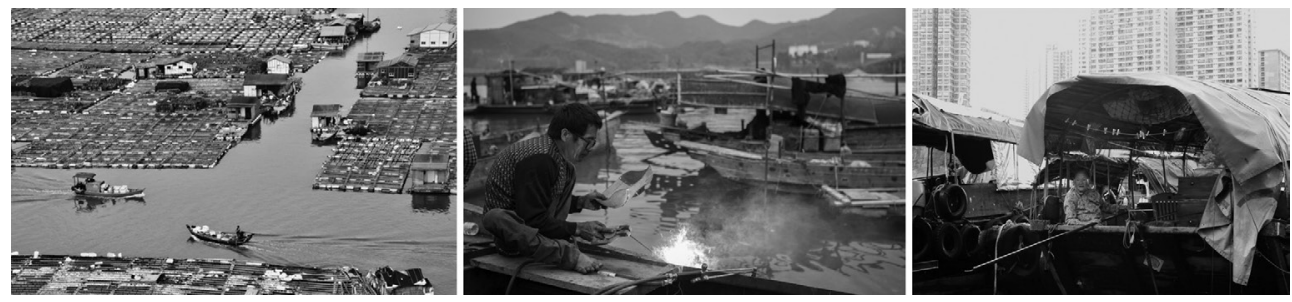

Figure 6: Villages of Aberdeen, Po Toi and Tai O in Hong Kong.

so sourcing from the natural environment as much as possible saves in cost. The simplicity of the design does the same by not using more materials than needed. A floating house needs to be balanced, and in all cases, the design needs to place elements proportionally for that balance to be found. A simple structure helps achieve this, something to be remembered.

Living mainly at Cheung Chau, Aberdeen, Kowloon Harbour, Tai O, Po Toi, Kau Sai Chau and Yau Ma Tei, I spent time in Hong Kong (Fig. 6) visiting the Tanka people in the summer of 2016. Etymologically the word Tanka is composed of Tank that is a Cantonese term for boat or junk and $k a$ that means family or peoples. It refers to a population of fishermen and cargo carriers who lived on their boats and rarely came on shore. This group referred to themselves as seui seung yan (People of the water), and they differentiated themselves from the land-dwelling communities around them, considering themselves to belong to separate ethnic groups, defined by ecology more than by language or culture. The Hakka and Cantonese lived on land; the Tanka and Hoklo lived on the water and were both classified as boat people. This differentiation is not unusual, throughout Asia; almost every country with rivers and coasts has its own boat people, all containing local traditional construction techniques and experiential knowledge for living on water. Today the boat communities are no more. Their bays have been filled to allow for the land expansion of Hong Kong. Their people have been forced on land to take jobs away from fishing which has succumbed to pollution and overharvesting or have been forced away from the bays around Hong Kong. The few that remain, living in houseboats, the same way they have for centuries, have a lot to teach us.

This brief diary is a portion of research I have been gathering for a book dealing with floating architecture. The goal of touching on some of these places is to show that there is much to be learned from these communities and their relationship to water. This knowledge can help cities dealing with the rise of sea level start planning towards the future of dwelling in water.

\section{CONCEPTUAL IDEOLOGY: THIRD NATURE}

Something I realized doing field work was how in all the vernacular examples previously mentioned, the communities are always in some way finding a balance between human intervention and natural ecology. As I researched about this type of balance, I came across the Idea of Third nature, which was presented by Flemming Rafn Thomsen and Ole Schrøder of the architecture and landscape firm Tredje Natur from Copenhagen Denmark at an Utzon lecture series in 2014 [1]. For them 'Third nature is a holistic perspective, that is based on the idea that the problems of the world cannot be solved by only thinking about the parts of the system and that a framework for a high quality of life is not achieved by solely looking at sustainability, aesthetics, solutions, cities or nature separately. Nature's value is built on the idea that everything in the world is interconnected and we must see the big picture for change to be possible' [2]. The floating dwelling proposal that functions as the result of the 
research this paper presents, borrows the concept of Third nature, which needs to first be understood in terms of defining what first and second natures are. The idea of First nature refers to the natural world. Sometimes used in a much romanticized way, it proposes the idea of an environment that is interdependent and to some degree in balance. Second nature is defined as the type of growth that takes place when the urban fabric is allowed to expand out of control, in an invasive unplanned way (like how it does in informal settlements or suburbs). When this happens, it always does so at the cost of what we defined as First nature. And the results are always detrimental to the quality of life of its inhabitants. Third nature then is a symbiotic hybrid that creates a system of interconnected elements designed to create a manmade balance similar to what I saw on my fieldwork. It is the capacity that design has to help architecture develop an interdependent system that is able to produce a new type of environment, mixing urban and natural components in a symbiotic way to educate, feed, empower and better the quality of life of the population. This hybrid needs to work at a micro- and macro-scale for it to be successful. In the specific case of the design project we are proposing, it needs to function at the residential and the urban levels. And it needs to do so in a manner that benefits the existing environment, by solving specific social and ecological issues as a result of its existence. This paper will cover the micro-scale.

\section{METHODOLOGY}

The idea of a live/work/farm dwelling typology comes from understanding that the residence has the potential to solve more urban problems that just the creation of shelter. I learned from observing communities related to water that the house needs to be versatile and adaptive. This perspective is especially important in a world dealing with a climate crisis. The house needs to solve as many aspects of our lives as possible so that the user is not dependent on external entities that are out of her/his control. The field work taught me the importance of self-sufficiency. Once the rise in sea level becomes part of the equation, the dwelling typology adapts and floats. At the end of the paper, we will see the result of research and design trying to solve the specific problem of designing a reinterpretation of a shotgun house for New Orleans, in a community with a propensity to flooding. This proposal was designed to start a dialogue about the potential of water dwelling in areas that did not need them in the past. To achieve a holistic proposal, the following methodology was developed:

- Travelled to several locations to do field work and document different floating dwelling systems around the world. This process served to generate a series of elements to be emulated on a floating proposal for a middle-class family in the south of the USA.

- A (1 month) workshop was set up in the Tonle Sap lake in Cambodia. Students lived in the community where they designed floating house based on existing materials, construction methods and social and cultural needs. The participants did field work and lived with the community.

- The research opened the door to a project within Tonle Sap lake for an NGO. The project was published ISSN-1743-3541, DOI: 10.2495/SC160551.

- Analysed all the entries for the Make it Right Competition sponsored by Brad Pitt, which proposed reinterpretations of the shotgun house to help New Orleans rebuild after Hurricane Katrina.

- An on-going design, assessment and re-design process in terms of ideation, implementation of new technologies and construction methods, management and maintenance cost was set up with the goal of developing a proposal. 
- By defining a site question, site specificity, environmental material impact, social impact, community involvement and prefabrication alternatives were studied and assessed.

- A design was created and taken to 'design development' stage so it could be reviewed by peer designers.

- Green technologies where researched and specified for the project to give the future owners options on the level of self-sufficiency they wanted to attain on the project.

\section{SITE}

The ninth ward is located in the city of New Orleans in the state of Louisiana (Fig. 7). This area experienced the city's most significant and longest standing flooding from the Hurricane Katrina in 2005. Most of the damage was caused by storm surge due to the levees failure. The flood created a violent current that not only flooded buildings but smashed them and displaced them from their foundations. A month later, before the neighbourhood had dried up and the water receded, it flooded again when Hurricane Rita hit the city. Historically, the site had a typology of housing called a shotgun house, which is a narrow rectangular residence with rooms arranged one behind the other and doors at each end of the house. And it was the most popular style of house in the Southern USA from the end of the American Civil War (1861-1865) through the 1920s. Today, the neighbourhood is full of empty lots, a reminder of the flood.

\section{CASE STUDY}

The process started by looking at the Make it Right Competition (2009) [3], which proposed some interesting ideas to deal with flooding. In that competition, the firm Morphosis from Los Angeles proposed a design based on technology used in the Nederland for a floating home. This concept had not been taken seriously in the USA until this moment. The house presented by Morphosis had two anchors and a floating base that allowed the house to lift up and down following the water level without moving from its location. This idea made me look into how designs in the Nederland had been dealing with holding a house in place. This

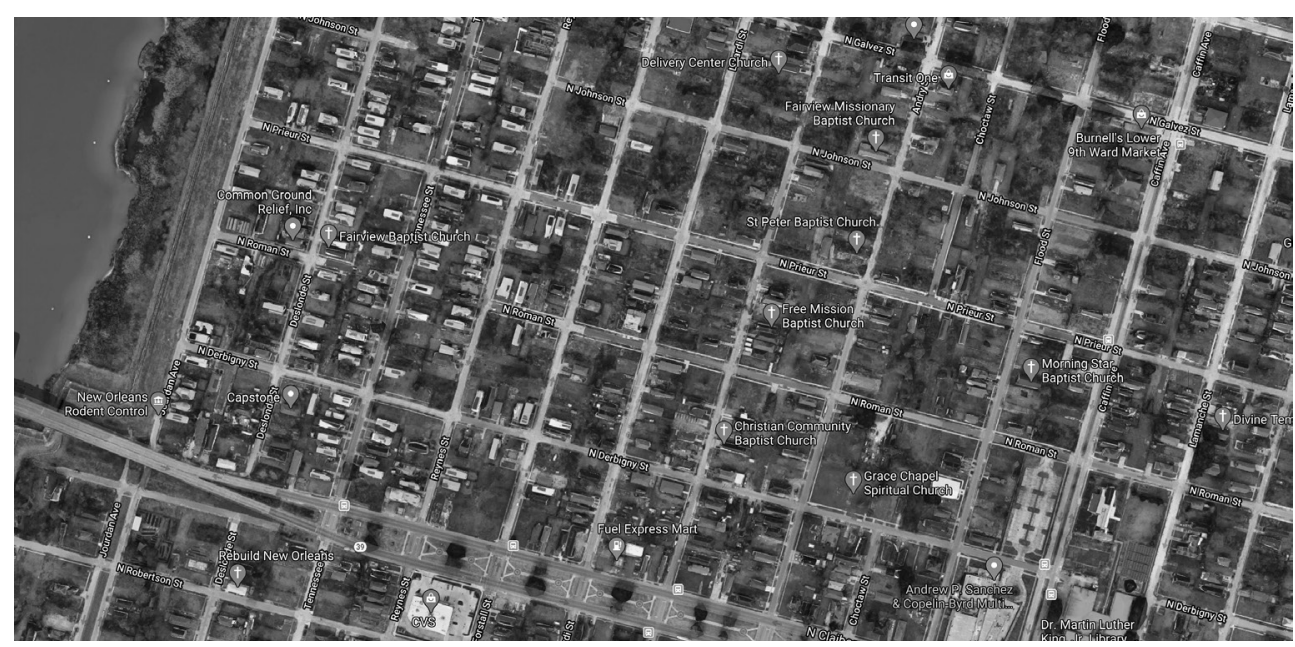

Figure 7: Ninth Ward neighbourhood in the city of New Orleans, USA. All the empty lots were houses lost after Katrina. 
was a very important element of the design, because the water current during Katrina forced some houses to move and crash against each other. If a design was going to float, it needed to remain in place to minimize damage of property and of the house itself. A house that shifted location due to the current would end up anywhere but on its intended location, and once water receded, it would be impossible to move. Structurally, the anchors should be the only element attached to the ground. The rest of the house needs to be free to move up when needed. In the original designs, plumbing proved to be a problem because any non-rigid pipes were open to leaks and malfunctions. Today, that is not a problem because we are able to make the house totally self-sufficient by composting its black water, recycling and filtering the grey water and producing its own water through atmospheric water generators and water catchment systems. So, by using a similar anchoring system than the house designed by Morphosis [4], our design is diagrammatically an elongated rectangle $\left(20^{\prime} \times 98^{\prime}, 6 \mathrm{~m} \times 30\right.$ $\mathrm{m})$ with two metal columns going through its interior. The height of the columns will be set to align with the future projected flood levels for the area, giving the system space to adapt to different scenarios. The anchors (called dolphins) are metal cylinders with a diameter of 20" $(0.5 \mathrm{~m})$ set off centre within the volume to balance the weight of the house. The anchors are attached to a concrete foundation in a wet dock comprising of retaining walls and a base slab. This system is similar to one first proposed by Baca Architects for a project on an island in the middle of the River Thames built in 2014 [5]. When flooding occurs, the dock fills with water and the house rises accordingly. The wet dock serves also to conceal the floatation base of the house allowing it to be just a little above grade. The wet dock and the anchors are the only elements built on site. The rest of the house is designed to be prefabricated off-site and brought in parts to be ensembled around the anchors.

The house is designed as an extruded volume with a common structural frame that repeats through the length of the house. The simplicity of the volume is very important in keeping with an even flotation. The volumes repetitive structure allows for the dwelling to be shorter or longer as needed by the inhabitants. Since the project is prefabricated, the size is set at the design phase with the interior being adapted to the needs of the client. The interior is designed for versatility by providing a clean internal volume where to configure the house. The idea is to provide a main volume with multiple internal options; from purely residential to residential with a workspace, residential with a commercial space, residential with a micro-factory, etc. The proposal presented as a case study (Fig. 8) is purely residential, but it does follow the live/work/farm model previously talked about. The way in which these three elements manifest functions on an interdependent system of design ideas meant to make the dwelling self-sufficient and better the quality of life of the inhabitants. But despite their interdependence, the best way to understand each of these elements is by looking at them independently. The live component is the residence as a whole. As you walk from the street, you arrive to a covered porch designed to resemble the spatial and social nature of the original shotgun houses, creating a space for contemplation and social interaction covered from the elements. Behind it the entrance and a large floor to ceiling window, which can open, when the weather allows it, blurring the interior with the exterior by making the porch an extension of the living room. The interior layout follows the one from the traditional shotgun house, with a hallway taking you all the way through the house, with the rooms feeding from this circulation axis. The front of the house is designed with an open plan, unifying living room, kitchen and dining room. The house has a 4-feet band that extends the length of the dwelling, concealing in it storage, vertical circulation, pantries, toilets, showers, a meditation room and two anchor access spaces. By creating this functional volume, the rest of the house can 


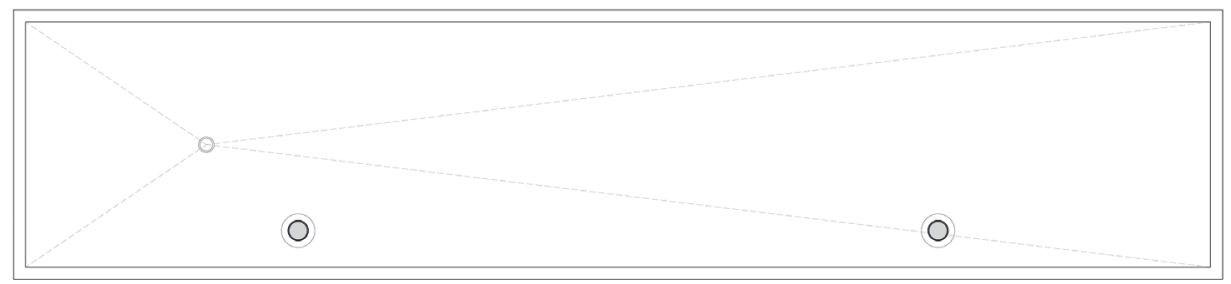

PLAN AT WET DOCK
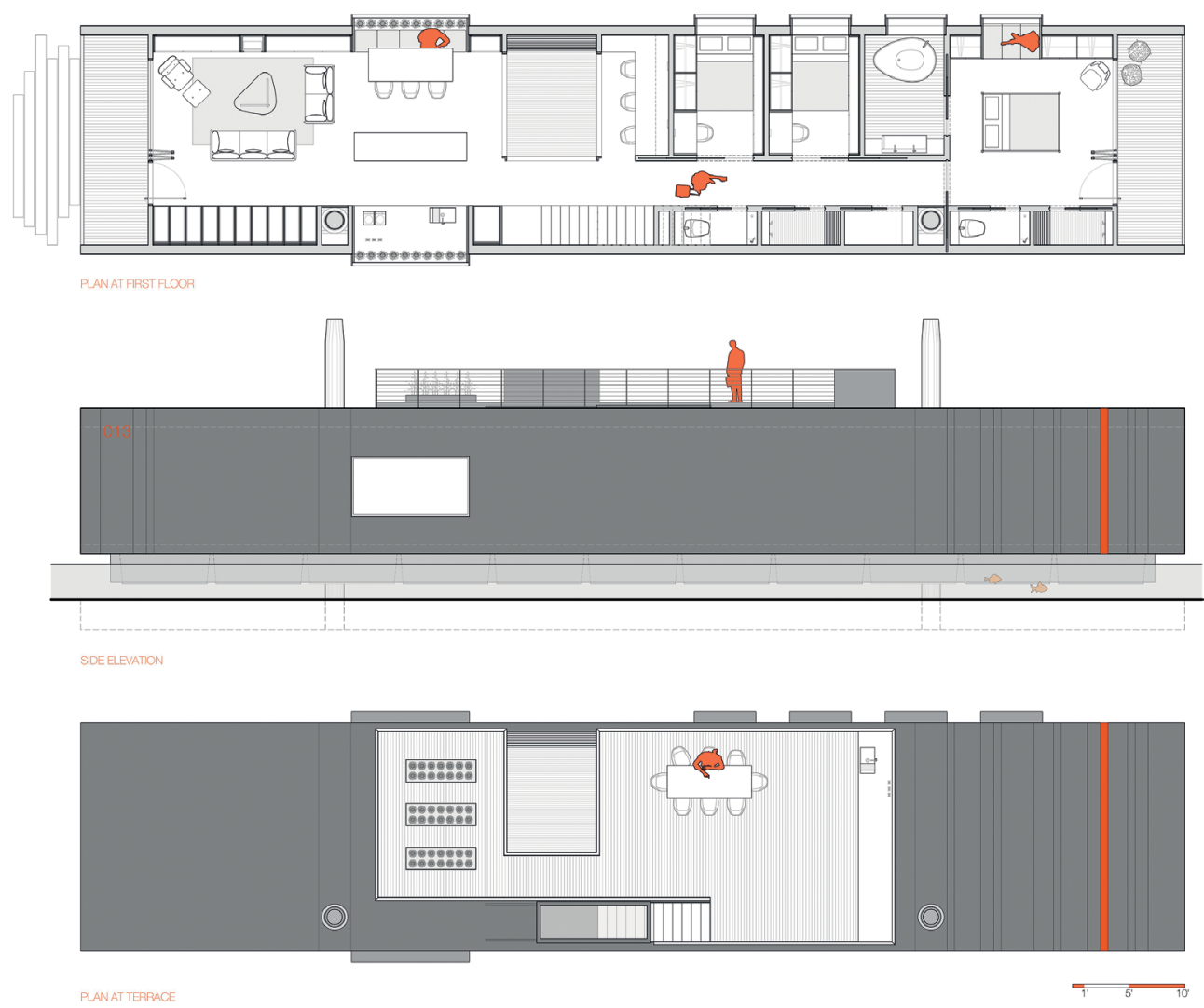

Figure 8: Plan at dry dock, Plan at first floor, side elevation and plan at terrace of Floating Shotgun House.

adopt a simplified layout. The hallway feeds to two smaller rooms and a master bedroom. The master bedroom has its own bathroom with a bathtub, but the showers and toilets are set on the functional band. Showers and toilets have been separated into single rooms so that they can be used by multiple people without interfering with each other. The master bedroom faces the back yard of the lot, with a floor to ceiling glass wall, composed of doors and windows, overlooking a covered porch. In the centre of the house, an internal garden separates the public and private parts of the house, allowing for direct illumination of the centre of the volume. This garden is open to above, meaning that when it rains, the inhabitants can 
experience the elements from within the house. The vertical circulation takes you to a terrace. The work component is sprinkled through the residence. Between the public and private parts of the house, and next to the internal garden, an office space is set for remote work and the small rooms; each has a desk area. Originally the idea is to allow for the back of the house to become a more specific workspace as mentioned before, but the client wanted only a station for working remotely. And finally, the farm component that appears as hydroponic systems on the two large windows on the kitchen and dining room, a mushroom farm drawer in the kitchen, soil farming on the terrace and the yard and worm composting on the terrace. These three components function interdependently through the dwelling making the house self-sufficient by producing a percentage of their food, energy and water, providing a space for remote working and housing a family of 4 in a 1,600 square feet $\left(150 \mathrm{~m}^{2}\right)$ house, right sizing the area of the home to what it would have been in the 1950s, half the size of a home for the same amount of people today. An interesting aspect of the design is the use of built-in furniture which provides the house with a lot of storage space saving the family from having to purchase unnecessary furniture. The living room is flanked by two linear built-in fixtures: the first is the functional band itself, which was explained previously. The other is a floor to ceiling shelving system composed of shelves, drawers, closed cabinets, a heating stove and a seating cubie for the dining table on the opposite wall. The two small bedrooms are a single built in piece of furniture comprising a bed, closet space and a desk. Both sides of the bed are floor to ceiling fixtures with a large window the size of the room behind the bed. The master bedroom has a continuation of the functional band and opposite to it a floor to ceiling wall of closet space and a seating nook with a window. The incorporating of built-in furniture to the design makes the house more functional and minimizes the amount of furniture purchased by the inhabitants allowing indirectly for a simpler way of life. To all these we have to remember the dwelling is smart home, with an array of technologies designed to make the house sustainable and self-sufficient.

\section{SMART HOME TECHNOLOGIES}

The term smart home or domotics (from the Latin domus, meaning home) refers to a type of dwelling that uses internet-connected devices to enable the remote monitoring and management of appliances and equipment, creating an interdependent system. Nowadays, technology allows us to control our home from our phone, making the idea of a live/work/farm dwelling typology [6] a lot simpler. This smart home will produce its own water through atmospheric water generators [7] and rain catchment systems, filter and recycle grey water from sinks and showers. Instead of producing black water, it will use composting toilets. It will produce its own energy from solar panels on the roof that will use a Tesla home battery (Powerwall) [8] for energy storage, heat its water with solar heaters and use energy saving appliances (energy star). It will hydroponically grow mushrooms in the kitchen and use vermicomposting bins (worm composting) to dispose of all organic waste. But before all that is functional, the house will be built using a thermal mass shell, all materials will be sustainable, reused materials or produced locally. The dwelling will also use its gardens to grow food and clean the air of the neighbourhood, waters the plants automatically and will use local flora not to consume more water than needed. It will use natural light as much as possible through skylights and solar tubes, using a smart thermostat to keep the house at an optimal temperature and will use an Artificial Intelligence (AI; home system) helping manage the systemic interdependence of all these elements. All the proposed equipment proposed is off the shelves and financially feasible paying for itself within 5 years of implementation.

And on top of all these, it floats by using cement-coated expanded polystyrene (EPS) pontoons [9]. 


\section{SUSTAINABLE DEVELOPMENT GLOBAL GOALS}

This project was designed to address sustainable development global goals: no hunger, good health, clean water and sanitation, affordable and clean energy, sustainable cities and communities, responsible consumption and production and climate action [10].

\section{CONCLUSION}

The aim of this project is to develop a floating typology of residential design that proposes solutions to the housing shortages due to population increase in coastal cities or areas prone to flooding, a dwelling typology designed to make us start thinking on the rise of the sea level. And to do so, understanding historical precedents as a way to inform the design process is necessary. But overall designing is with the aim to address local needs and better the inhabitant quality of life, by providing:

- An urban farm system capable of providing the user with food all year around, intended to provide better nutrition, air quality, passive income and financial savings to the household.

- Energy independence through the use of solar power.

- The capacity to filter and re-use grey water through the residence and urban farm.

- A workspace that adapts to the future requirements of the world tendency to work remotely.

- The decrease in waste product (black water) due to composting technologies.

- A floating system that is easy to build and maintain.

This residential proposal provides a conceptual framework designed to address not only dwelling as a self-sufficient system, but it also addresses the systemic interdependency between dwelling and community as they participate in the development of a new type of environment for living. Moving into the water redefines the idea of home and neighbourhood, but thanks to the relationship of some cities to their coast lines, it does so as an evolution of pre-existing ideas, making the move to the water a natural next step on urban growth for cities with land scarcity and areas prone to flooding.

\section{AKNOWLEDGMENTS}

I would like to thank the American University of Sharjah for providing the grants that have allowed me to visit Hong Kong, Laos and Myanmar and for supporting my research.

\section{REFERENCES}

[1] Flemming Rafn Thomsen, Third Nature. Towards empathetic, transparent and engaging cities, UTZON (x) Lecture series, fall 2014, 13:00, October 8th, Create campus.

[2] Agnete Schimmell Raakjær, Ole Schrøder og Flemming Rafn Thomsen, 2017, Nature Value, tredje natur, http://tredjenatur.dk/en/nature-value/. Accessed: May $19^{\text {th }} 2019$.

[3] Building Green, Making it Right in New Orleans- A tour of rebuilding in the Ninth Ward of NOLA, with green homes designed by some of the world's leading architects, Building Green, 2011. [On-line] https://www.buildinggreen.com/blog/making-it-rightnew-orleans. Accessed: May $28^{\text {th }} 2019$.

[4] Alarcon Jonathan, The Float House-Make it Right/ Morphosis Architects, Arch Daily, 2012. [On-line] https://www.dezeen.com/2014/10/15/baca-architects-amphibious-housefloating-floodwater/. Accessed: May $28^{\text {th }} 2019$.

[5] Winston Anna, UK's 'first amphibious house' can flat on floodwater like a boat in a dock, Arch Daily, 2014. [On-line] https://www.archdaily.com/259629/make-it-righthouse-morphosis-architects. Accessed: May $28^{\text {th }} 2019$. 
[6] Cerro Camilo, Next Generation Habitation Typologies: Live/Work/Farm, WIT Transactions on Ecology and the Environment, Vol. 226, WIT Press 2017, pp 219-226. ISSN:1743-3541 (On Line).

[7] Wahlgren Roland V., Water-from-air Quick Guide: An Atmoswater Knowledge Product, CreateSpace Independent Publishing Platform, 2016. ISBN: 1523-6388-18, 97815236-3881-9.

[8] Tesla Motors, "Powerwall Tesla Home Battery," 2015. [Online] https://www.tesla.com/ powerwall Accessed: May $28^{\text {th }} 2020$.

[9] Yulianto Purwono Prihatmaji, Dimas H. Nugraha, Keeping the Floating House Afloat in Banjarmasin: Implementation Potential of EPS Floating Technology for Foundation Engineering, 2019, pp 6-9. DOI: 10.1051/matecconf/201928002001

[10] Unite Nations Sustanable Development Goals Knowledge Platform, Helping Governments and Stakeholders make the SDGs a reality, 